\title{
"Literate Playing"-An Oral Language Empowerment Strategy for Underprivileged Children
}

\author{
GISELA WAJSKOP \\ Pontifical Catholic University of São Paulo
}

\begin{abstract}
This article describes an ongoing collaborative action research study, and presents initial observations of the outcomes of teachers' interventions in early childhood education centres in a major Brazilian city. Designed as a professional development initiative, the action research is based on a view of a quality program being one that offers both playbased learning and linguistically enriching experiences for children and opportunities for professional learning of its professionals to support those same programs in a personal, self-confident, and collective manner. It presents initial observations of the outcomes of teachers' interventions in four non-governmental early childhood education centres, and some implications the results can suggest for the NOW Play Project.
\end{abstract}

\section{Introduction}

Investment in the first three years of life-whether through educational programs or isolated actions with families - has become one of the priorities of Brazilian government policies in the last decade. The complementarity of Brazil between education and careand integrity in the development of the child in daycare centres-became a childhood policy since 1988 with the New Democratic Laws (Brasil, 1988).

Since then, children became represented to society as capable instead in need of care. ECE became children's right for education and care as citizens. (Nunes et al., 2011). The most recent legal document that defines the National Curriculum Guidelines for Early Childhood Education (Brasil, 2010) points to giving priority to discussions on how to guide the development of children's play and oral language, as well as recognizing their participation in the cultural world as well as the importance of development of children in daycare centres. Although discourses change, few policies have been made: coverage rate is still 25.6\%, which represents only 3.2 million Brazilian children, revealing a substantial space for expansion of supply, especially for the poorest children. Only $21.9 \%$ of children enrolled in daycare centres come from $25 \%$ of the poorest Brazilian families that need more educational and care attention and who remain at home in absolute poverty (Brasil, 2017).

When it comes to public daycare centres that enrolled most of the poor children, Brazil still faces major challenges to establish and implement quality programs consistent with the legal frameworks for early childhood education of the new Brazilian democracy. Recent studies on the quality of daycare centres in Brazil (Campos et al., 2011) reveals weak implementation of the Ministry of Education's mandatory guidelines and quality standards (e.g., Brasil, 1998, 2006, 2009, 2010) especially when it comes to reading and oral activities, and children's play (Campos, Coelho, \& Cruz, 2006; Kramer, 2009; Medeiros, 2013). Nevertheless, it has been shown that children's regular attendance in quality daycare centres boosts equality and its effects can have a lasting beneficial impact 
whenever there are sound quality programs available (Campos et al., 2011, pp. 29). Brazilian laws and documents defined quality programs based on political, ethical, and aesthetic principles from the National Mandatory documents (e.g., Conselho Nacional de Educação, 1999; Ministério da Educação, 2010; Brasil, 2014), which advocate that every child has the right to be cared-for and to learn, in a respectful local culture. This would include play-based learning which provides opportunities for language experiences and knowledge environments (Ministério da Educação, 2010, pp. 16). Quality is also defined by coverage in attendance, by the ratio of children/teacher, by teachers having a bachelor's degree that includes pedagogical courses and practice teaching and, finally, by safe and healthy infrastructure. The influence of quality childcare should be more significant for the poorest children because educational institutions can offer them cultural, social, cognitive, affective and emotional development opportunities, which may not be always accessible within their families of origin (Barros et al., 2009; Brasil, 2017). This also means that daycare centre attendance can offer children literate environments rich in experimentation, exploration and research experiences, as well as play activities that enable them to grow and develop into creative and self-confident individuals.

Attendance at quality daycare centres and pre-schools also contributes to success in the early years of primary school (Campos et al., 2011). Research shows that low-quality institutions - which don't have an educational and healthy infrastructure, childhood educational program and qualified practice teachers supported by the municipalitiesmay not have a significant impact on children's current educational performance (Amaro et al., 2015) as well as on their future ones (Barros et al., 2009). The author states, "The quality of the activities and program structure heavily impacts the development of the child." (Barros et al., 2009, pp. 227).

Other studies reveal that many early childhood teachers do not have the qualifications needed to develop a quality early childhood program in full-day care centres (Campos, 1999, 2003; Campos et al., 2006; Gatti, 2010; Kishimoto, 2005). Campos, Füllgraf, \& Wiggers (2006), for example, have found that daycare teachers and educators do not, themselves, have the knowledge about child development and care to interact with and help them grow up. In another study, Campos et al. (2011) showed there are few institutions in Brazil that provide enriching experiences for children and support regular training activities for educators to be able to provide quality programs. In response to this identified need for professional learning initiatives for daycare teachers, my colleagues and I proposed a collaborative action research project, modelled after the NOW Play project in Canada (Peterson et al., 2010).

This article describes an ongoing collaborative action research study and presents initial observations of the outcomes of teachers' interventions in early childhood education centres in a major Brazilian city. Designed as a continuing professional development strategy, the action research is based on a view of a quality program as being one that offers both play-based learning and linguistically-enriching experiences for children and opportunities for professional learning of its professionals to support those same programs in a personal, self-confident, and collective manner. Our research addresses the following question:

What are the content and teaching strategies needed to collectively build and bring together the knowledge brought by the children into their play in order to 
foster the development of literacy and, more specifically, the oral language of three and four year olds?

\section{Theoretical Constructs}

A technical report on the recent survey about the quality of early childhood education (Campos, Coelho, \& Cruz, 2006) showed the evident influence of experiences offered to children regarding their oral expression. According to this work "children who have opportunities to hear explanations, opinions, excuses, stories and are encouraged to do the same, formulate longer and more elaborate sentences" (Campos, Coelho, \& Cruz, 2006, pp. 74). The survey also revealed most of the Brazilian poor children interviewed construct very short sentences, and a large number of them give single-word answers. The authors suggest the fact "may be associated with the type of weak work with oral activities offered in most institutions attended by poor children in our country" (Campos, Coelho, \& Cruz, 2006, pp. 75).

Studies have shown language development of children during play and how such activities enhance both their oral language development as well as their literacy education (Peterson et al., 2010; Pellegrini \& Galda, 2000; Sawyer \& DeZutter, 2009). They may also update current pedagogical practices, which contribute to continuing education training for the teachers and educators involved.

The significant use of language in specific cultural contexts to be created by teachers and educators within the institution may lead children to learn expectations, meanings, values and perspectives of their culture as well as vocabulary, grammar, basic phonology and semantics for their own language development (Teberosky \& Jarque, 2014; Peterson, 2014; Elkonin, 1987; Goncü, 1999).

The hypothesis that gave rise to this work is that there can be an enrichment of play and children's oral language learning whenever adults create successful experiences of reading books aloud to children. We believe that reading aloud can provide linguistic and imaginative models for children to incorporate them into their play, favouring the development of literacy and, more specifically, the expansion of verbal communicative skills and playful narratives, even leading to spontaneous written production.

In this perspective, this paper considers three interconnected concepts, as described below, namely: (1) Children's Play-Based Learning; (2) Oral language as the foundation of cultural learning; (3) Culturally relevant monitoring.

\section{(1) Children's Play-Based Learning}

Our action research project is underpinned by a view of play as important to young children's learning (Bodrova, 2008; Dahlberg, Moss, \& Pence, 2003; Goncü, 1999; Pellegrini \& Galda, 2000; Wajskop, 2004, 2012; Wajskop \& Peterson, 2015). Such centrality has been present in many public policies in Brazil (Brasil, 2010) as well as in countries with good international models of early childhood education such as Australia and Canada (Australia, 2009; Ontario, 2010-2011). According to a recent official document for public consultation, play is one of the main activities where children learn. Simple interactions such as holdings objects and elements of nature, recognizing the behaviour of peers, enjoying a musical performance or a story being told are also great learning experiences (Brasil, 2016, pp. 19-20).

This article understands play as both a social practice and also a particular language of childhood. (Pellegrini \& Galda, 2000). 


\section{(2) Oral language as the foundation of cultural learning}

The social constructivist theories (Elkonin, 1987; Goncü, 1999; Vygotsky, 1984, 2003) based on the idea that learning occurs in social contexts is at the core of this work. According to Peterson (2014) based on Halliday, it is in the everyday and ordinary use of language with parents, brothers and sisters, children of their neighbourhood, at home, on the street and in the park, shops, trains and buses that we convey to children the essential qualities of a society and of the social human nature. Through meaningful use of language in specific cultural contexts, children can also learn the expectations, meanings, values and perspectives of the culture in which they live as well as vocabulary, grammar, basic phonology and semantics suitable for the language development of young children. (Soares, 2016; Teberosky \& Jarque, 2014).

Thus, we gave priority to reading children's books aloud in order to create a particular cultural context - a real social practice - to be consistently implemented by teachers in a monitored way, to create language and imaginative experience conditions different from those experienced by the child within his/her family unit every day.

\section{(3) Culturally relevant monitoring}

The monitoring of children's achievements should involve the use of everyday language and also be culturally and linguistically appropriate to the suggested play. The monitoring of children's language progress is made with the aid of recording devices, as well as with the observation of the teachers ${ }^{1}$ involved, by taking into consideration the meaningful narratives created during contexts of play. The development of children's language has been monitored in authentic contexts of heuristic and spontaneous play during the course of our investigation and on several occasions in the classroom. This helps update teaching practices and improve learning experiences for children, and it also works as content material for professional development. Instead of assigning diagnostic labels for the classification of children, monitoring the development of language in play contexts during their regular interactions conducted by adults or simply those that take place spontaneously among peers has been a tool for updating pedagogical teaching practices in order to help enrich childhood experiences (Peterson et al., 2010).

\section{Research Design: Action Research}

\section{Methods}

This paper is framed by assumptions about a collaborative action research as a possibility to teachers engaging in reflective inquiry, often with the guidance of an experienced colleague or a university facilitator/researcher who serves as a mentor. (Peterson et al., 2012).

In agreement with Tripp (2005), we consider the collaborative action research approach to be a forum for teachers and researchers to improve their teaching as well as their investigative practices and, consequently, to have a positive effect on children's learning.

According to Peterson (2012), the first assumption underpinning action research is an assumption that active participation and opportunities to reflect on own experiences

\footnotetext{
${ }^{1}$ In Portuguese, the teachers and educational professionals who work directly with children will be identified in the feminine gender, since women are the vast majority of them.
} 
and assumptions are integral to adult learning. Teachers can collect data from their classroom, reflect and make decisions regarding particular teaching practices for their children and classroom context.

A second assumption underpinning collaborative action research is that teachers' knowledge about their own students - about their classroom and the community context and teaching — provide the foundation for research decisions and practices.

A third assumption is that local knowledge is essential for accurate understanding of children's needs within specific classroom contexts. They are able to ask about specific practices, gather data daily and observe students systematically and regularly over long periods of time.

Researchers may provide specific questions and ideas that would not be available otherwise because of teachers' limited time for professional reading and lack of research experience. They are considered co-researchers who value and seek to draw on teachers' professional knowledge and expertise.

To achieve these goals, as a mentor/researcher, I started observing and videorecording two classes, and then used my observations and recordings in the actionresearch meetings with teachers. We discussed how to observe children and what we could learn when we watched and re-watched children interacting in their play after reading aloud for them. After three meetings, it was agreed that teachers would present their video recordings in an internal seminar. 23 teachers collected 23 videos of children's interactions in free or heuristic play. The average duration of each video recording was 1-to-5 minutes each. After being recorded, videos were posted to Google Drive or sent to me via email for transcription and analysis. They were watched and analysed in 5 monthly action-research meetings for a year, ensuring the collective and collaborative construction of the pedagogical proposal.

Teachers also transcribed, reported, documented (in an individual portfolio), and general reflections were gathered in a collective notebook when action-research meetings occurred. Five hours' worth of meetings were recorded.

\section{Context and Participants}

This research has been carried out in four different daycare centers in a nongovernmental institution of a large Brazilian city. This institution was selected as a research context because of its relevance to the history of public daycare centers in poor Brazilian suburbs of big cities during the 1970s. It was created as a result of struggles and mobilization of women during the Movement for Day Care Centers that took place during the 1970s (Rosemberg, 1984). It proved to be an important leader in early childhood education in Brazil, and its influence can be felt to this day. Since the beginning, its mission was based on community: to respect children and appreciate the local culture by making sure they had the right to play. Through education and culture, it aims to rescue citizenship, dignity and improve the lives of children, teenagers and adults of the community.

Additionally, the researcher has been a volunteer student, an educational consultant and, a Board member of the institution.

The action-research has been going on since March 2015, and it involves teachers from its four different daycare centres. Children aged zero to 3.11 years spend their whole day there, from $7 \mathrm{am}$ to $5 \mathrm{pm}$, which are located in a low-income neighbourhood in 
a big city. $70 \%$ of children enrolled there come from families earning up to 3 minimum wages $^{2}$ and another $30 \%$ of them earning up to 10 minimum wages monthly. Teachers come from the same community as the children, and most of them are the first in their family to have university studies. They earn up to 3 minimum wages monthly for 44 hours per week.

Table 1

Staff and Number of Children

\begin{tabular}{lllll}
\hline $\begin{array}{l}\text { Day } \\
\text { care }\end{array}$ & $\begin{array}{l}\text { No/Age of } \\
\text { children }\end{array}$ & $\begin{array}{l}\text { Average } \\
\text { children } \\
\text { per } \\
\text { teacher }\end{array}$ & $\begin{array}{l}\text { Teachers: } \\
\text { assistants }\end{array}$ \\
\hline A & 140 & $2-3.11$ & 12 & $11: 2$ \\
B & 140 & $0-3.11$ & 12 & $13: 2$ \\
C & 160 & $0-3.11$ & 10 & $15: 3$ \\
D & 160 & $0-3.11$ & 10 & $15: 3$ \\
\hline
\end{tabular}

We found, after 20 years of its implementation, a play-based pedagogy where the "livreiras" (door storage pockets) are still used in all rooms, and infants and toddlers are in constant contact with books, which are sometimes read aloud to them. The presence of classroom book collections was the result of an organization of the books in each one of the units. Management and teachers had the initiative to do so and created a cloth support with plastic pockets in which children can see the covers of books. These "livreiras" are much like the ones in which we can place our shoes. There is a practice of telling stories based on a book's images and pictures.

Children play in dramatic-play hairdresser environments, playhouses, pretend school sets, and toy castles, complete with dolls and strollers. Although it is a regular practice in educational institutions to use the terms 'nooks' or 'corners' to refer to the space for play, we will use the term 'environment' or 'stations' consistent with the idea of 'environment experiences' defined and proposed by the National Curriculum Guidelines for Early Childhood Education-DCNEI-(Brasil 2010). The terms 'nooks' or 'corners' create the opposite desired effect, for they bring the idea that play activities are 'pushed' to the nooks or corners of the rooms, as residual activities since the central activities are undertaken by the adults.

\section{Action Research Starting Points}

In one of the classrooms where we recorded a video, we were able to observe that four of the 18 children present spoke very little. In another class with 17 children, we observed an activity in which children had to read their names and their colleagues' in flashcards, which revealed an old schooling method. In this classroom only 3 children read all the names while all the others only read their own names, and 5 of the children seemed to be guessing at them.

These observations served as the starting point for a discussion with teachers in an action-research meeting on the work done with children and the demands for the

${ }^{2}$ The National minimum wage is $\$ 300$ US monthly, or $\$ 1$ US per hour. 
construction of new educational paradigms associated with the development of oral language and literacy based on books and free play.

The scenes we watched and discussed in one of the training meetings showed children spontaneously playing with real life themes, expressed through the use of phrases or meaningful words such as: "am goin' wo'k now", "taking care our baby", "already back wo'k?", "sleep son" 3 . While the expressions used by children to play revealed their understanding of everyday life, they also revealed the construction of important oral language. While playing, children used the oral language to explain their peers their playful actions.

In one of such scenes, there is a girl and a boy playing side by side. He is holding a chunk of play dough, a rubber elephant and a tiny pot. She is playing with a doll and a chunk of play dough as well. The boy "eats" some of the play dough and uses the tiny pot to pretend to feed the rubber elephant. The girl has a (naked) doll on her lap while playing with the play dough. The boy approaches her and asks, "Did HE poop?"emphasizing the male gender in his speech. She quickly replied: "SHE did." After that, she turns her doll and begins to move it, whereupon the doll's penis becomes apparent. The boy laughs and points to the penis, trying to touch it. The girl says: "It's MY baby!" and sits the doll in front of her (G. Wajskop, field notes of recorded video, June 29, 2015).

One can see here that play allowed these two to think about the meaning of the words regarding the genitals of the doll and the gender assigned to it, while using words to construct the plot of their playing.

In another scene,

While the girl feeds the doll, the boy says: "Want pacifier!" To which the girl replies: "Want pacifier? Here." And gives him a "litt'e airplane car". The boy immediately puts the object into his mouth sucking its tip as one would a pacifier. The girl is watching and the boy nestles beside her, and she says, touching his face: "Now go sleep."

After a few seconds the boy says, "Already up. Up."

Girl: "Up?"

Boy: "Up! Go school! “

Girl: "Go school?"

Boy: “Go wo'k.” (Wajskop, recorded video, June 29, 2015)

These two scenes show an evolution of the narrative of the children associated with familiar everyday scenes: sleeping, sucking pacifiers, going to work, accompanied by:

- Gestures and sounds;

- Clear naming of objects whose meanings are transformed by language;

- Definition of roles through the use of appropriate and negotiated language;

- Dialogues and plots from specific contexts.

We can also see that for such interaction between the girl and the boy to work, certain requirements had to be met for it to last more than 4 minutes without interruption:

\footnotetext{
${ }^{3} \mathrm{We}$ chose to transcribe the speech of children exactly like they verbally expressed themselves. There were small adaptations to the English language. The original Portuguese sentences were: "vai tabalá, agola?" "eu vou ficá cuidando do nosso nenê ... " "já voutô do tabalo?" "dómi filho ....".
} 
1) The two had to communicate clearly the meaning of the changes brought on to the object, as well as their gestures or actions that would be accepted by the partner, as in the case in which the girl said that despite the doll's penis, it was being used as "her baby" (with the feminine designation of it in Portuguese);

2) These clarifications and negotiated settings such as the doll gender definition and the decision the child would work and would not go to school took an important part of the playtime, establishing itself as an ongoing and spontaneous narrative.

\section{More Systematic and Intentional Interventions as Part of Action Research Process}

Based on the previous scene, we presented our thoughts to the research team: (a) all these issues go unnoticed by teachers in everyday care, which would demand a more accurate observation as well as a more careful log of the teaching materials used (Edwards, Gandini, \& Forman, 2016); (b) this scene is based on everyday knowledge to be expanded and transformed.

With this in mind, the team of teachers established a more systematic and intentional line of work with the 'door storage pockets' and books, that were defined as the most appropriate strategy for the expansion of the linguistic universe of the children.

Twelve (12) reports were gathered in a first training meeting (as letters to the researchers). They represented the thirty-eight (38) teachers in attendance, who were divided into groups of three, and were presented the criterion of choice within a collection of books and their proposed activities. We found two themes-or interesting categories - to be further explored (Charmaz, 2014) associated with the choice of books. Half of the letters (reports) reflected a preference for books with a clear disciplinary theme and moral aspects such as: teaching children to apologize; talking about prejudice, gender and race; autonomy; facing fears; and taking on responsibilities. The other half of the letters demonstrated a preference for book titles based on genre: rhymes, illustrations, and text. The results were discussed in groups where the force of morality themes in the community was considered as well as the need to enhance their oral language, the latter deemed as more important than taking on the responsibility to teach morals. This new line of action was decided together.

In subsequent training meetings, teachers and assistants chose titles to read aloud to children. The main criteria chosen of such books were the linguistic and aesthetic aspects of the texts as opposed to the previous moral criteria.

The choice of reading aloud was due mainly to the fact most of the stories told in the classrooms are done so by teachers. Each teacher tells it in his/her own way, with different words and, sometimes, even changing the meaning of the words. We discussed the fact that storytelling is a common practice in daycare centers because it facilitates children's contact with books, especially where teachers are poorly educated.

Nevertheless, the team decided reading aloud would be the best teaching strategy to enrich playing and it could also create opportunities for children to think about the written language. The strategy of reading aloud is for the purposes of sticking to the identity of the narrative. The stability of the written text can, in this way, provide a literacy environment by introducing children to text, sound, writing, and the meaning of words.

Among its many advantages, reading aloud provides the following benefits, as stated by Culliman and Galda (2000, pp. 135-136): 
- Provides opportunities for children to hear fluent reading;

- Increases children's vocabulary: as they listen to new words in interesting texts, they can use them in other significant situations;

- Provides different types of narratives, such as rhymes, stories, descriptions, etc.;

- Increases children's storehouse of experiences, through the situations and characters presented;

- Allows children to make connections among books. They can compare writers styles, noticing what it is that writers do;

- Provides object-handling models and how to turn pages;

- Helps children develop their own ideas about writing - more particularly about its regularity - so they can understand that words are always the same, regardless of how many times the stories are read.

We then read and chose rhyming books, as well as narratives of pirates, circuses, and other descriptive - or even fictional- texts about different animals. From there, participants planned activities for a month's work with the groups. The regularity of the activities allowed them to observe the impact of reading books in the play and oral language development of children. They read and showed the pictures, setting them apart from the text several times and for several days, avoiding to tell them based on their memories. They provided conditions so the children could have literacy experiences based on the familiarity with the books as a text carrier. In order to do this, the teachers also showed them the name of the authors and illustrators, talking about authorship and characteristics of different book genres.

Of the various experiences developed and presented in an internal seminar-which took place only a month after the beginning of the investigation - we chose one of the experiences to illustrate the results of the work with the book "Smelly Bill" (Postgate, 2010). The book is inventive, comprehensive, provocative, and has a character that seemed exemplary for the rest of the team ${ }^{4}$.

One Example of Action Research Intervention Based on the Book "Smelly Bill"

Like most of her colleagues, this teacher took a book from the institution's newly updated library collection to her classroom, which had been previously selected by the group. She was featured because she was the first teacher who pushed a reflection within other teachers of the impact her interventions had on children's learning. She chose "Smelly Bill", a fun book filled with rhymes that tells of the antics of Smelly Bill, a dog that loves to play in the dirt. He loves smelly things, like muddy ponds and rubbish bins. Her choice sought to relate to her classroom's curiosities and taste. Choosing a rhyming book had the goal of increasing the linguistic possibilities of children, assisting them in expanding their vocabulary use through an entertaining story with which children would find easy to identify.

In response to the project under discussion, the teacher read the story several times for the children. After the first reading, the children produced a collective drawing, followed by the individual production of booklets, so that we could evaluate their

\footnotetext{
${ }^{4}$ Special thanks to the teacher of the class that not only gave researchers full access, but authorized the publication of the results of the project carried out with the children using the book "Smelly Bill."
} 
takeaway. Most of them scribbled, so we did not identify the presence of any kind of relationship with the story they had just listened to and there were also no traces of spontaneous writing.

The teacher later proposed a number of activities in order to integrate the book and its narrative with the story of the class. She brought a dog and a turtle for the children to observe and explore their characteristics such as hair texture, snout shape, and the number of legs, in order to establish a comparison with the information provided by the book. At this point, we could notice the children using new words they had just learned from the book to describe and compare the animals. The difference between the dog's hair and the turtle shell was what caught their attention the most. Furthermore, they used the word 'snout' and 'moustache' - presented in the text and new for most of them- to describe and differentiate the dogs: the real ones from the fictional ones. At a later moment, the teacher suggested they created a papier-mâché Bill puppet, using plastic bottles and caps so they could play with it later. They then had the opportunity to take part in different activities, such as mixing paint to create colours as well as making a snout, paws, and tail from papier-mâché. During this activity, children produced and imagined the dog from the book with the help of their teacher, but they were mostly able to anticipate and plan the activity using phrases and words from the text read. "Fred" (the dog's Brazilian name from "Smelly Bill" in translation) was then positioned next to the book, available to play.

The book was available to the children via the 'door storage pockets', and they used it in several ways: they went through the pages alone, in pairs, or in trios, enacting the reading practices used by the teacher. They also pretended to read the book aloud to themselves as well to their friends. The teacher recorded the children correcting each other when using phrases derived from the book in an attempt to faithfully reproduce the written text read by the teacher.

In the process that lasted over a month, besides observing and registering the children's testimonies, the teacher produced small note pads shaped like little books in which they were able to draw individually. Many of them registered the title and author's name in their own way. Also, besides presenting more elaborate drawings, most children spontaneously made different forms of writing.

Outdoor and inside play received new objects and characters: Bill, the dog; a turtle; Great-Aunt Bleach - all characters from the book-and also a tank in which to wash imaginary clothes, among other things. The teacher reported that children started to use new words in their dialogues while pretending to wash and hang clothes on clotheslines or as they walked the papier-mâché dog. Words like smelly, grimy, hair, legs, snout and moustache started to be a part of new narratives and dialogues created during their playtime. Smelly Bill—both the book and its papier-mâché recreation-became a part of their oral practices and their play when they spontaneously reproduced entire sentences from the book as their own.

What We Are Learning about Supporting Children's Language: Implications for Northern Canadian Contexts

\section{Children's play-based learning}

The emotional, affective, cognitive, cultural and social benefits of play for children

have been known for quite some time. As an activity that is constituted by and in children's language, it is a unique opportunity for children, whether alone or in a group, 
to try and use their abilities to transform the meanings of objects, gestures and actions through words. By using concrete support such as objects, toys or gestures to create their play, children were able, for the first time, to dissociate the literal meaning of the word and create new semantic relationships between what they see and what they mean whenever in action.

During this process, some authors believe a rich relationship between play and the construction of children's narratives is developed (Pellegrini \& Galda, 2000). During playtime children can understand new knowledge and beliefs (representations of reality) taking on different roles or characters.

In order to adapt the use of objects to play (such as the little plane that turned into a pacifier in one of the scenes described above) the children had to access some metarepresentational cognitive abilities (when an object is represented as something else in that individual's mind) to construct their own playing, along with the spontaneous interactions we observed (Smith, 2009, p. 10). This occurred also in some of Northern Canadian videos, such as "Camping Dramatic Play". As transcribed from the video:

"The kindergarten teacher created a camping-themed dramatic play centre using a small fold-up tent, three sleeping bags and a few non-camping related items (e.g., pine cones and blocks). While the children played in this centre, they talked with each other about camping and were free to use the props in any way they needed. During this first week of the camping dramatic play centre, the teacher would also group the children together to explore themes around camping, using both props and imagination. For example, she brought in cotton balls and sticks and asked the children what they might do with these. One boy used the sticks to build a "fire" and the cotton balls then became "marshmallows". Another time, the teacher brought an imaginary picnic basket to the carpet and suggested that they needed to fill it. She had wooden blocks to serve as props. The students suggested that the blocks become items for a recipe, and they contributed suggestions to a recipe for "rainbow juice". The teacher emphasized the different senses to see how these descriptions might relate to camping. For example, she pretended to feel something wet, which led to students sharing their ideas about water and then about going fishing. The classroom items that the teacher brought into the lessons became imagined camping related items." (Video transcript, from personal correspondence, May 2016)

In both situations, by making use of objects, toys or objects with altered meanings, children were able to imagine themselves as someone different and create imaginative dialogues that allowed a spontaneous and collaborative narrative to emerge.

\section{Oral language as the foundation of cultural learning}

In our observations, whenever they played with toys whose evident characteristics had to be modified - for example, disregarding the gender of the doll and referring to it by the feminine pronoun ela ("she") — children developed a high degree of literacy because they had to think, communicate, and negotiate with their peers the words used to modify the objects with which they were playing.

After reading aloud, we found that Bill (the papier-mâché dog) had become part of the play. With the mediation of the puppet, children used new words in consensual play 
interactions. The book's text expanded the oral repertoire of children and made it possible to enrich their play beyond the objects with which they were already familiar.

During several moments throughout their play, children in pairs, trios, or quartets would use phrases from the book, such as "Smelly Bill will take bat! [ . . ] No! Auntie Bleach told him" or, for example, "He was duped! Let wash it? Yeah all grimy!" A new narrative was gradually created in a highly rich cognitive and linguistic process in which children added and changed the words and their own roles in a continuous indeterminate series of events. If we compare to the "Camping Dramatic Play" video, we can find the same idea about oral language as the foundation of cultural learning. The Canadian teacher had found that both groups - morning and evening classes - of children gave different names for the same objects/props, depending upon their own experiences camping and their own imaginings. The teacher noticed the same thing in the campingplay centre, for example, some children referred to the tent as a camper, while others called it a tent, depending upon the narrative that they were creating. With the camping centre, she noticed that the students had very different experiences around camping, and so she wanted to explore this further. [...] She encouraged the children to draw pictures and write words to contribute to the word wall in the dramatic play centre (NOW Play project transcript, personal communication, May 27, 2016).

Our ongoing investigation has revealed that, just as actual toys such as dolls or props as used at the Camping Dramatic Play, reading literary books - especially fiction stories with familiar themes and rhymes-provides content for play. Reading aloud encourages children to talk and play as if they were the characters in the stories, creating opportunities for the understanding of oral narratives while playing with them.

Our study shares similarities with a previous work (Istomina, cited in Bodrova, 2008 , p. 360) in which the number of words that children could remember and use during a game in a make-believe grocery store were higher than those used in classical experimental educational activities. In that work, children had to list words from a shopping list and were more successful in doing so, than when they were simply given a list of words to memorize and repeat.

As we have shown by the results of reading "Smelly Bill", our research confirms that there was an expansion and diversification of the use of oral and other modes of language by children in situations of everyday interactions. More importantly, however, we noticed that their play was enriched and expanded the children's oral language as well as gestures and other modes of communication.

Would those Brazilian reflections inspire Northern Canadian teachers? Should we ask about how children in Brazilian preschool and Northern Canadian Aboriginal Head Start classrooms use language and other modes of communication to achieve social purposes in their play?

\section{Culturally relevant monitoring}

In the world of early childhood education, it is traditional to create opportunities

and offer different types of material for children with which to play freely, with minimal adult intervention. Authors have reported frequent conflicts of interest between playing and teaching (Rogers, 2011; Wajskop, 2012) as if both activities were not two sides of the same coin. This division between play and education-characteristic of various educational practices found in children's education-has resulted in inadequate proposals 
for children's learning, including oral language skills, for it prevents the integration of play and pedagogical practices (Rogers, 2011, p. 5) as well as focuses exclusively on educational objectives (Wajskop, 2012).

Our research, in contrast, has shown that planned and intentional activities with children's literature (such as reading books aloud) can provide them with rich linguistic repertoire and imagination. The analysed results lead us to believe that play-inspired and enriched by children's literature read aloud by adults in daycare centres - may be a key strategy for the development of children's oral skills.

The playing analysed has shown to have impact also on children's familiarity with letters as well as their literacy process. Other Canadian videos showed the same results, as we saw in "Responding to Folktales": Grade 1 Indigenous children listened to the story "The Three Billy Goats Gruff". During the week, the teacher reread the story and the children participated verbally, and with actions and gestures. They created masks in the drama centre for their enactments, and later were asked to write the story or create a new version.

By using new words and expressions learned from the books to name objects and actions in their playing, children develop naming and description skills as well as semantics explanation at the same time they become more aware of the significance of their use. The books read enhanced the oral skills of children in situations where the use of new words was necessary and also enabled them to develop meta-linguistic awareness - i.e., the meaning of the words - and the expansion of their imaginative skills.

Burying the myth of the misleading debate concerning playing and early education, the study leads us to reiterate that there is an intrinsic and interdependent relationship between play, language and literacy (Pellegrini \& Ryzin, 2009).

We found that education - by means of cultural interventions by the teachers - can enrich and qualify children's play when developing intentional teaching practices such as the meaningful reading of books in daycare centres. We can say that by investing in research on the expansion of linguistic and narrative repertoire of children through literature, teaching activities can create conditions for children to take ownership of literate language. This means they develop the ability to produce and understand the formal language used in educational institutions. Play turns into a creative exercise of spoken language, where children can use new words and understand sense units in playful interactive contexts. Thus, rather than mere innate behaviours, play becomes a language activity.

We can say from the results, that by enriching children's oral skills with the reading of books and offering them open-ended props, teachers created opportunities to turn playing into a literate activity.

\section{What we are Learning about Supporting Professional Learning: Implications for the}

\section{NOW Play Project}

Finally, throughout this process, one learns more about this by carefully examining the practice as well as the research itself. In this perspective, we have developed a work related to the reflection and registration of teaching practices, investigating how the use of personal narratives associated with the importance of teaching practices can impact the change of attitude and vision about the profession. 
First of all, a number of participants reported the impact of learning about research practices such as observation and video-recording as tools for later reflection. Secondly, they reported the use of individual notebooks as tools of thinking. Through writing and reading their own notes and ideas, they became their own mentors.

A number of participants reported that their action research impacts their teaching practices. It made them aware of the need to provide opportunities for children to be free to choose a story to read. Many of them also reported that they became aware of the impact on children's learning and imagination of reading aloud rather than telling a story. They also started to see themselves as a model for children as they became more attentive to their own language, correcting each other.

One teacher reported that their action research made them aware of the necessity to hear children's needs to learn in a process through play. Many teachers reported that their action research made them aware of children's voice. One teacher reflected that her action research confirmed her understanding about the importance of listening to the children for better teaching.

We agree with Peterson (2012) "through participation in action research, teachers become more adept at collecting and evaluating evidence of children's learning and using this information to refine and improve their teaching." (p. 5). According to Peterson, action research "also fosters teachers' greater confidence in their practice, a greater sense of professionalism, and a greater depth of knowledge. The professional growth of teachers through opportunities to reflect on each other and with their mentor to make sense of their experience and develop their own theories and principles of effective practice." (p. 5).

Through their participation in action research, teachers began to reflect more deeply about their own practice in a learning community, articulating intentions, assumptions, and connections with theory.

As reported, one teacher participating in their action research has changed their children's approach as well as their own teaching.

Finally, there is still much to do, but it has become clear that the appropriation of new, significant, and creative teaching strategies that take children's rights into account takes time. However, a big step was taken, indicating the possibility of collectively building a pedagogy based on literature and 'literate play' that creates fairer opportunities for poor children to take ownership of communication processes, expression and linguistic meanings by fluent and creative use of oral language within early childhood institutions.

Supporting professional learning of teachers from low-income Brazilian communities made us aware of the impact that collaborative research could have on teachers' practice. In a deepened understanding, supporting professional learning showed us the power of helping teachers to become theorists. They amplified their understanding about poor children's right to learn and the classroom context in a new cultural meaning, becoming more than just a good teacher. They became aware of the power of their own teaching and their cultural interventions within poor children's rights to play and learning in daycare centres as well as the power of collaboration between research and teaching.

Our action research could have some implications for the NOW Play project because of our similar cultural context. Northern Canadian teachers, just as our own communities' teachers, could go beyond the profession and theory. If participating in 
collaborative action research provided opportunities to make Brazilian teachers be aware of children's voices as well as their own, Northern Canadian teachers may also think about children's aboriginal voices as well as theirs in a school learning context.

\section{References}

Australia. (2009). Belonging, being \& becoming: The early years learning framework for Australia. In: Australian government department of education employment and workplace relations. Retrieved from: https://docs.education.gov.au/node/2632

Barros, R. et al. (2009). A importância da qualidade da creche para a eficácia na promoção do desenvolvimento infantil [The importance of quality child care in its effectiveness in promoting child development] (pp. 210-230). Retrieved from: http://www.abc.org.br/IMG/pdf/doc-2004.pdf

Bodrova, E. (2008). Make-believe play versus academic skills: A Vygotskian approach to today's dilemma of early childhood education. European Early Childhood Education Research Journal, 16(3), 357-369, doi:10.1080/13502930802291777

Brasil. (1998). Ministério da Educação e do Desporto. Secretaria de Educação Fundamental. Referencial curricular nacional para a educação infantil [National curriculum framework for early childhood education]. Brasília, Brazil: MEC/SEF, $3 \mathrm{v}$. Retrieved from: http://www.planalto.gov.br/ccivil_03/leis/leis_2001/110172.htm

Brasil. (2006). Parâmetros nacionais de qualidade para a educação infantil [National quality parameters for early childhood education]. Retrieved from: http://portal.mec.gov.br/seb/arquivos/pdf/Educinf/eduinfparqualvol2.pdf

Brasil. (2009). Ministério da Educação/Secretaria da Educação Básica. Indicadores da qualidade na educação infantil [Quality indicators in early childhood education]. Retrieved from: http://portal.mec.gov.br/dmdocuments/indic_qualit_educ_infantil.pdf

Brasil. (2010). Ministério da Educação. Secretaria de Educação Básica. Diretrizes curriculares nacionais para a educação infantil [National curricular guidelines for early childhood education]. Brasília, Brazil: MEC, SEB. 36.

Brasil. (2014). Diário oficial [da] República Federativa do Brasil [Official gazette [of the] Federative Republic of Brazil]. Brasília, DF, Brazil. Retrieved from: http://www.planalto.gov.br/ccivil_03/_Ato2011-2014/2014/Lei/L13005.htm

Brasil. (2016). Proposta da Base Nacional Comum Curricular [Proposal of Common National Base Curriculum]. Ministério da Educação. Secretaria de Educação Básica. Secretaria de Educação Continuada, Alfabetização, Diversidade e Inclusão. Ministério da Educação. Secretária de Educação Básica. Diretoria de Currículos e Educação Integral-Brasília: MEC, SEB, DICEI. Documento para Consulta Publica. Retrieved from: http://undime-sc.org.br/download/proposta-dabase-nacional-comum-curricular/

Brasil. (2017). Aspectos dos cuidados das crianças de menos de 4 anos de idade [Aspects of care for children under 4 years of age]. 2015, IBGE, Coordenação de Trabalho e Rendimento. Rio de Janeiro, Brazil: IBGE, 2017. IBGE, Coordenação de Trabalho e Rendimento. Rio de Janeiro, Brazil: IBGE. Retrieved from: http://biblioteca.ibge.gov.br/visualizacao/livros/liv100137.pdf 
Campos, M. M. (1999). A Formação de professores para crianças de 0 a 10 anos:

Modelos em debate [Teacher training for children from 0 to 10 years old: Models in debate]. Educação \& Sociedade (Número especial: Formação de profissionais da educação: políticas e tendências), v.20, n.68, 126-142, dez.

Campos, M. M. (2003). Profissionais de educação infantil: Desafios para a política educacional [Childcare professionals: Challenges to educational policy]. In: A.J. Severino \& I.C. Fazenda (org.), Políticas educacionais: o ensino nacional em questão [Educational policies: The national education in question] (pp. 151-161). Campinas, Brazil: Papirus. (Série Cidade Educativa).

Campos, M. M., Coelho, R. C., \& Cruz, S. V. (2006). Consulta sobre qualidade da educação infantil: Relatório final [Consultation on the quality of early childhood education: Final report]. Textos FCC, 26: 101.

Campos, M.M., Füllgraf, J., \& Wiggers, V. (2006). A qualidade da educação infantil brasileira: Alguns resultados de pesquisa [The quality of Brazilian early childhood education: Some research results]. Cadernos de Pesquisa, 36(127), 87-128. https://dx.doi.org/10.1590/S0100-15742006000100005

Campos, M. M., et al. (2011 jan./abr.). A contribuição da educação infantil de qualidade e seus impactos no início do ensino fundamental [The contribution of quality early childhood education and its impact on early childhood education]. Educação $e$ Pesquisa, São Paulo, v.37, n.1, 15-33.

Charmaz, K. (2014). Constructing Grounded Theory. London, England: Sage Publications.

Cullinan, B., \& Galda, L. (2000). Reading aloud from culturally diverse literature. In D. Strickland \& L.M. Morrow, Beginning reading and writing (pp. 134-142). New York, NY: Teachers College Press.

Dahlberg, G., Moss, P., \& Pence, A. (2003). Qualidade na educação da primeira infância: Perspectivas pós-modernas [Quality in early childhood education: Postmodern perspectives]. Porto Alegre, Brazil: Artmed.

Elkonin, D. (1987). Problemas psicológicos del juego en la edad preescolar [Psychological problems of playing in the preschool age]. In: (Antologia), La psicología evolutiva y pedagógica en la URSS (pp. 83-102). URSS: Editorial Progreso.

Edwards, C., Gandini, L., \& Forman, G. (2016). As cem linguagens da criança: A experiência de Reggio Emiglia em transformação [One hundred languages of the child: The experience of Reggio Emiglia in transformation], v.2. Porto Alegre: Penso.

Gatti, B. (2010). Formação de professores no Brasil: Características e problemas [Teacher education in Brazil: Characteristics and problems]. Educação $e$ Sociedade, 31(113), 1355-1379. Retrieved from: https://www.scribd.com/doc/166345871/Gatti-Formacao-de-Professores-NoBrasil

Goncü, A. (1999). Children's engagement in the word-sociocultural perspectives. Cambridge, England: Cambridge University Press.

Kishimoto, T. M. (2005). Pedagogia e a formação de professores(as) de educação infantil [Pedagogy and early childhood teacher education]. Pro-Posições, São Paulo, 
16(3), 181-193, set./dez. Retrieved from: http://www.proposicoes.fe.unicamp. $\mathrm{br} /$ proposicoes/edicoes/texto28.html

Kramer, S. (Org.). (2009). Retratos de um desafio: Crianças e adultos na educação infantil [Portraits of a challenge: Children and adults in early childhood education]. São Paulo, Brazil: Ática.

Medeiros, F. (2013). O Brincar nos documentos oficiais do ministério da educação para a educação infantil: Análise de aspectos relevantes para o desenvolvimento da criança [Play in official documents of the ministry of education for early childhood education: Analysis of relevant aspects for child development]. Universidade Estadual de Maringá, Brazil: Trabalho de Conclusão de CursoTCC, apresentado ao Curso de Pedagogia. Retrieved from: http://www.dfe.uem.br/TCC-2013/Trabalhos2013/FRANCIELY_JOICE_.pdf

Nunes, M.F.R., Corsino, P., \& Didonet, V. (2011). Educação infantil no Brasil: Primeira etapa da educação básica [Child education in Brazil: First stage of basic education]. Brasília, Brazil: UNESCO, Ministério da Educação/Secretaria de Educação Básica, Fundação Orsa. Retrieved from: http://unesdoc.unesco.org/images/0021/002144/214418por.pdf

Ontario. (2010-2011). Ontario Ministry of Education. The Full-Day Early LearningKindergarten Program. Draft Version. Retrieved from: http://www.edu.gov.on.ca/eng/curriculum/elementary/kindergarten_english_june3 .pdf

Pellegrini, A., \& Galda, L. (2000). Children's pretend play and literacy. In: D. Strickland $\&$ L. Morrow, Beginning reading and writing (pp. 58-65). New York, NY: Teachers College Press.

Pellegrini, A., \& Rysin, M. V. (2009). Commentary: Cognition, play and early literacy. In: K. Roskos \& J. Christie, Play and literacy in early childhood: Research from multiple perspectives, 2nd ed. (pp. 65-80). New York, NY: Routledge.

Peterson, S.S. (2012). Action research supporting students' oral language in Northern Canadian schools: A professional development initiative. Journal of Research in Rural Education, 27(10), 1-16. Retrieved from: http://jrre.psu.edu/articles/2710.pdf

Peterson, S.S. (2014). Goal and project description [Internal use paper]. Toronto, ON: Ontario Institute for Studies in Education - University of Toronto, 2014.

Peterson, S.S., Krpan, C., Swartz, L., \& Bennett, W. (2010). University faculty, colleagues and teachers' federation as mentors in collaborative action research. McGill Journal of Education/Revue des sciences de l'éducation de McGill, 45(2). Retrieved from: http://mje.mcgill.ca/article/view/4644/6485

Postgate, D. (2010). Fred, o cãozinho fedorento (E. B. de Araujo, Trans.) [Smelly Bill]. São Paulo, Brazil: Editora Zastras.

Rogers, S. (2011). Play and pedagogy - A conflict of interests? In: S. Rogers, Rethinking play and pedagogy in early childhood education: Concepts, contexts and cultures (pp. 5-18). New York, NY: Routledge.

Rosemberg, F. (1984). O movimento de mulheres. E a abertura política no brasil: O caso da creche [The women's movement. And the political opening in Brazil: The case of daycare]. Cad. Pesq., São Paulo, (51), 73-79. Retrieved from: http://www.fcc.org.br/pesquisa/publicacoes/cp/arquivos/564.pdf 
Sawyer, K., \& DeZutter, S. (2009). Improvisation: A lens for play and literacy research. In: K. Roskos \& J. Christie, Play and literacy in early childhood: Research from multiple perspectives, 2nd ed. New York, NY: Routledge.

Smith, P. (2009). Pretend play and children's cognitive and literacy development: sources of evidence and some lesson from the past. In: K. Roskos \& J. Christie, Play and literacy in early childhood: Research from multiple perspectives, 2nd ed. (pp. 319). New York, NY: Routledge.

Soares, M. (2016). Magda Soares discute como mediar o processo de aprendizagem da língua escrita [Magda Soares discusses how to mediate the learning process of written language]. Plataforma do Letramento. Retrieved from: http://www.plataformadoletramento.org.br/em-revista-entrevistadetalhe/393/magda-soares-discute-como-mediar-o-processo-de-aprendizagem-dalingua-escrita.html

Teberosky, A., \& Jarque, M. (2014). Interação e continuidade entre a aquisição da linguagem e a aprendizagem da leitura e da escrita [Interaction and continuity between language acquisition and reading and writing learning]. Cadernos Cenpec| Nova série, 4(1). http://dx.doi.org/10.18676/cadernoscenpec.v4i1.276

Tripp, D. (2005). Pesquisa-ação: Uma introdução metodológica [Action research: A methodological introduction]. Educação e Pesquisa, São Paulo, v. 31, n. 3, set./dez. 2005, 443-466. Retrieved from: http://www.scielo.br/pdf/ep/v31n3/a09v31n3

Vygotsky, L. S. (1984). A formação social da mente [The social formation of mind]. São Paulo, Brazil: Martins Fontes, Ed.

Vygotsky, L. S. (2003). Linguagem, desenvolvimento e aprendizagem [Language, development and learning]. São Paulo, Brazil: EDUSP.

Wajskop, G. (2004). O papel da brincadeira na educação das crianças pequenas [The role of play in childhood education]. Avisa Lá (Centro de Estudos e Informações Crecheplan), 17, 9-15.

Wajskop, G. (2012). O brincar na educação infantil: Uma história que se repete [Playing in early childhood education: A story that repeats itself]. Questões da Nossa Época-34(9a.) ed. São Paulo, Brazil: Cortez editora, v. 1., 128.

Wajskop, G. (June 29, 2015). Diário de campo [Field journal]. Mimeograph.

Wajskop, G., \& Peterson, S. S. (2015). Dramatic play as a meaning-making and storymaking activity. Early Childhood Education, v. 43, 17-20.

\section{Author Biography}

Dr. Gisela Wajskop currently teaches at Pontifical Catholic University of São Paulo.

She has experience in the area of education, with emphasis on early childhood education, play-based learning, initial teacher education and higher education 